\begin{tabular}{|c|c|}
\hline & $\begin{array}{l}\text { International Journal of Trend in Scientific } \\
\text { Research and Development (IJTSRD) }\end{array}$ \\
\hline 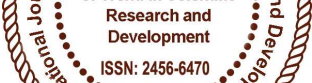 & International Open Access Journal \\
\hline 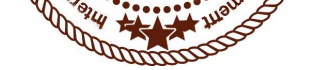 & ISSN No: 2456 - 6470 | www.ijtsrd.com | Volume - 2 | Issue - 2 \\
\hline
\end{tabular}

\title{
Impact of Climate Variability on Apple Production in Shopian District, Jammu and Kashmir
}

\author{
Parveez Ahmad Rather \\ Ph. D Research Scholar, Department of Economics, \\ Annamalai University, Annamalainagar, Chidambaram, Tamil Nadu, India
}

\section{ABSTRACT}

Decreased productivity of Apple orchards in the recent years has become a serious concern of the growers in Jammu and Kashmir particularly Shopian District. The apple yield has shown continuous fluctuations from last five years in the district, although the area of cultivation has steadily increased from 19770 hectares in 2008-09 to 21595 hectares in 2014-15. The factors which influence yield are climate, soil, cultivars, rootstocks, spacing and cultural management practices. Whereas all these factors influencing yield are manageable, the climate factors are beyond the control. The appearance of certain diseases and pests in epidemic form has also adversely affected apple production in recent years. The outbreak of pre- mature leaf fall and apple scab disease in the last five years remained persistent problem of the apple growers. Apple production and meteorological data during the past 9 years indicates great role of abnormal climatic factors during flowering and winter chilling requirements in lowering apple production. Among all the climatic factors rainfall during flowering seems to be most crucial factor in apple crop productivity in the study area.

Keywords: Apple, Production, Productivity, Fluctuations, Climate Variability, Apple Diseases

\section{INTRODUCTION}

District Shopian (study area) is known as the 'Apple Bowl' of the state as it is famous for horticulture and quality apple. Horticulture has assumed great importance in the economy of the district. As per the data maintained by Horticulture department the area under fruits during 2015-16 was 26166 hectares. Apple alone accounts $82.5 \%$ of area under horticulture crops. District Shopian is the third largest apple producing belt of Jammu and Kashmir after Baramulla and Kupwara. The production of apple in Shopian has increased from 190477Metric tones in 2007-08 to 248044 metric tons in 2015-16. The area under apple in Shopian under this period shows a study increase but the production and productivity shows enormous fluctuations (Table 1). The area under apple constitutes $94.4 \%$ of total under fresh fruits and $82.5 \%$ of total fresh and dry area in Shopian in 2025-16. The production constitutes $96.5 \%$ among fresh fruits and $92.5 \%$ of total dry and fresh fruits. These figures indicate the dependency of the district on apple cultivation.

Table 1 Area and Production and Productivity of Apple Fruit in Shopian District from 2007-08 to 2015-16

\begin{tabular}{|l|l|l|l|}
\hline Year & $\begin{array}{l}\text { Area } \\
\text { (Hectares) }\end{array}$ & $\begin{array}{l}\text { Production } \\
\text { (MT) }\end{array}$ & Productivity \\
\hline $2007-08$ & 19332 & 215440 & 11.1 \\
\hline $2008-09$ & 17786 & 202105 & 11.36 \\
\hline $2009-10$ & 18517 & 190963 & 10.31 \\
\hline $2010-11$ & 18814 & 220266 & 11.7 \\
\hline $2011-12$ & 21615 & 235129 & 10.87 \\
\hline $2012-13$ & 21625 & 197506 & 9.1 \\
\hline $2013-14$ & 21641 & 219395 & 10.1 \\
\hline $2014-15$ & 21595 & 226748 & 10.5 \\
\hline $2015-16$ & 21607 & 248044 & 11.47 \\
\hline
\end{tabular}

Source: Chief Horticulture Officer Shopian 


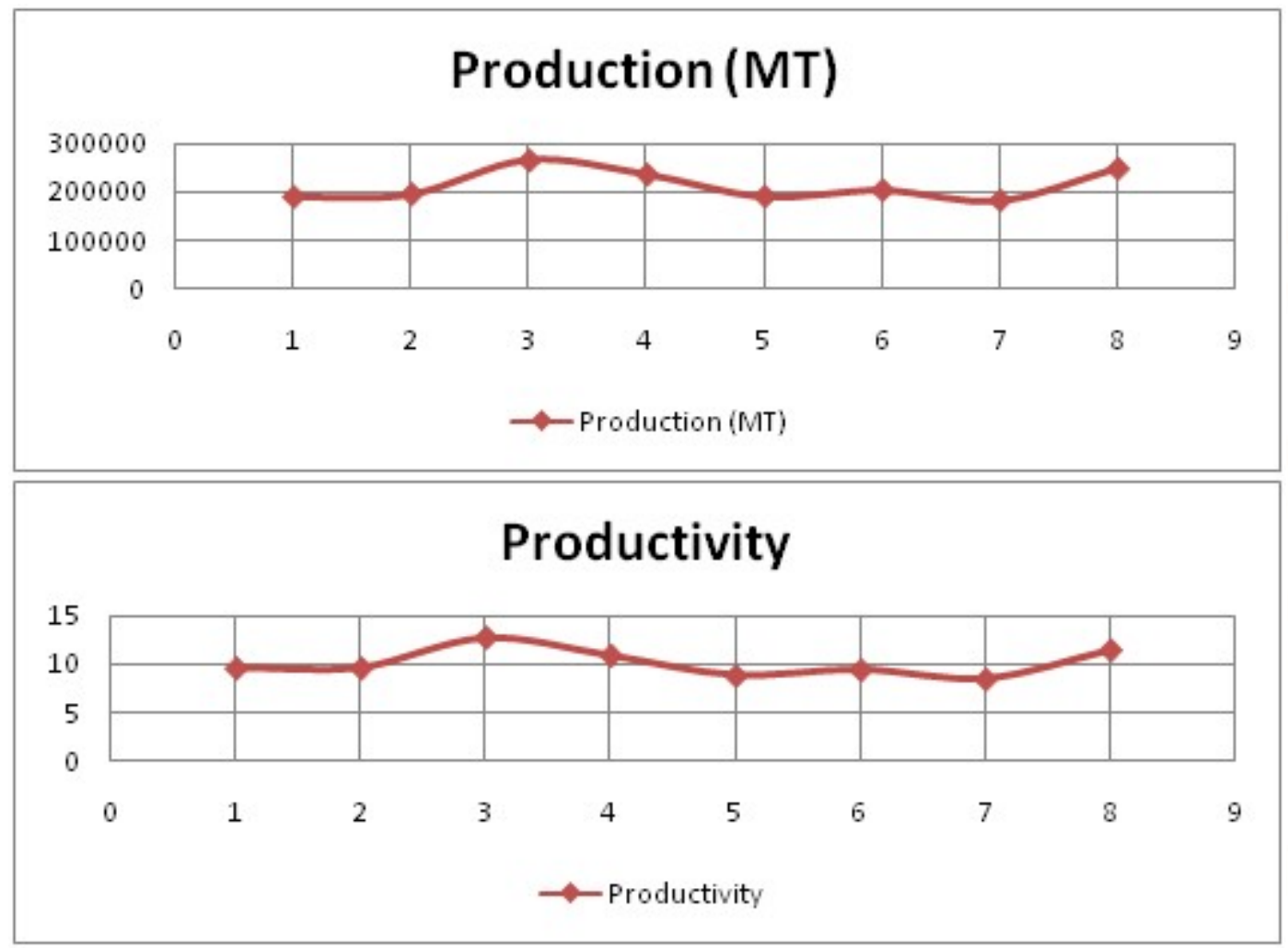

Figure 1: Production and productivity of apple in Shopian

Climate variability refers to shorter term (daily, seasonal, annual, inter-annual, several / years) variations in climate, including the fluctuations associated with dry or wet events. Climate variability is different from climate change. Climate change refers to long-term (decades or longer) trends in climate averages such as the global warming that has been observed over the past century, and long-term changes in variability (e.g. in the frequency, severity and duration of extreme events). If these parameters show year-to-year variations or cyclic trend, it is known as climate variability.

For few decades now, the Kashmir valley is bit by bit showing signs of change in its climate patterns. It's witnessing snowless Chilla-i-Kalans ${ }^{1}$ for many years now. In line with several scientists and specialists, if such a trend continues in future, it will have serious ramifications for the Valley. Kashmir is getting more snowfall in the month of February and March now, since earlier, it accustomed be in the month of January(Kashmir Dispatch/The Hindu- 2016). Deficit in food production is growing in Jammu \& Kashmir area. With the reduction in precipitation, the

\footnotetext{
${ }^{1}$ Chillai-Kalan, is the 40-day period of harsh winter. Chillai Kalan begins from December 21 and ends on January 31 next year)
}

rain-fed agriculture can suffer the most. Farming crops like apple are showing decline in production much owing to decline in snowfall. About thirty fourth and thirty ninth of the wooded grids are possible to bear shifts in vegetation kind with a trend towards exaggerated incidence of the wetter forest sorts (ENVIS-2015).

The fluctuating climatic parameters (temperature, rainfall and snowfall) from last seven years are a great sign of climate variability in Shopian District.

\section{Climate Requirement for Apple Farming}

Apple can be grown at altitudes 1500-2700 meter above mean sea level. In the Himalayan range which experience 1000-1,500 hours of chilling (the number of hours during which temperature remains at or below $7^{0} \mathrm{C}$ during the winter season). The temperature throughout the growing season ought to be around $21-24^{\circ} \mathrm{C}$. For optimum growth and fruiting, apple trees would like 100-125 mm. of annual rainfall, evenly distributed during the growing season. Excessive rains and fog near the fruit maturity period results in poor fruit quality with improper color development and fungal spots on its surface. Area exposed to high velocity of winds is not desirable for apple cultivation. 
Apple production and meteorological data during the past 9 years indicates great role of abnormal climatic factors during flowering and winter chilling requirements in lowering apple production. Among all the climatic factors rainfall during flowering seems to be most crucial factor in apple crop productivity in the study area, however the role of fluctuating winter temperature and snowfall and hails from flowering to harvest in lowering the production and fruit quality cannot be ignored.

The productivity and quality apple is influenced by I) spring conditions during flowering (April), ii)) post bloom summer conditions (June-July) and iii). Winter Conditions (December-February) ${ }^{2}$.

1) Spring: Flowering period is the most sensitive stage of plant development in apple so far as climatic conditions are concerned. The flowering of delicious apple occurs in the month of April i.e. in between $2^{\text {nd }}$ to $25^{\text {th }}$ April in Shopian. The flowering period remains about 15 days, because there is a variation of about 10 days between the lower and high altitude, the flowering period in Shopian is considered the whole month of April. During good crop years of 2011 and 2015 the maximum temperature at the time of flowering remained between $20.5^{\circ} \mathrm{C}$ to $24.8^{\circ} \mathrm{C}$. (Table 5.1). During 2009 and 2012, a poor crop year the maximum temperature at the time of flowering was in the low range of $17.7^{\circ} \mathrm{C}$ to $18.1^{\circ} \mathrm{C}$.

Again the majority of spring rains recorded during flowering in the year 2009 was $215.2 \mathrm{~mm}$. resulted a poor crop year. Fluctuating temperature during this period particularly rains compared by low temperature inhibits the transfer of pollen because of restricted bees activity and washing off of pollen in addition to retarding the pollen tube growth. The low temperature at the time of flowering and fruit setting also adversely affects production of fruits. It has been established that the flowers are killed below $2.2^{\circ} \mathrm{C}$ and bee activity is completely stopped below $4 \cdot 4^{\circ} \mathrm{C}$.
2) Summer: The climatic conditions during summers i.e. fruit development stage (June-July) influence not only the size and quality of fruits but also the flower bud differentiation affecting flowering seasons crop. The dry and hot summers affect the fruit development and quality, as the fruit size remains small. The optimal temperature during summer for proper growth and development is $20-24{ }^{\circ} \mathrm{C}$. The climatic parameters during summer in the district also fluctuate but did not influence the production much. The minimum temperature during the fruit period ranged from 13.1 to $16.6{ }^{\circ} \mathrm{C}$. The maximum temperature remains between 25.8 to $29{ }^{\circ} \mathrm{C}$ during summer with well distributed rains ranging from 108.1 to 215.2mm during 2007-2015. The year 2011 experienced a good crop year followed by two bad crop years with low quality fruits despite a good summer with maximum temperature ranged between 27.5 to $29^{\circ} \mathrm{C}$ with well distributed rains due to recurrent hails of high intensity during fruit set and fruit development period (Kashmir Times- 2012).

\footnotetext{
2 Jindal et. al (2004) Apple Production in Changing Climate Scenario: Issues and Constraints. Recent Horticulture Trends in The Himalayas. Indus Publishing Co. New Delhi, p. 68
} 
International Journal of Trend in Scientific Research and Development (IJTSRD) ISSN: 2456-6470

Table 1.2 Variation in apple production in relation to fluctuation in temperature and rain fall at Flowering Stage in Shopian district, Jammu and Kashmir

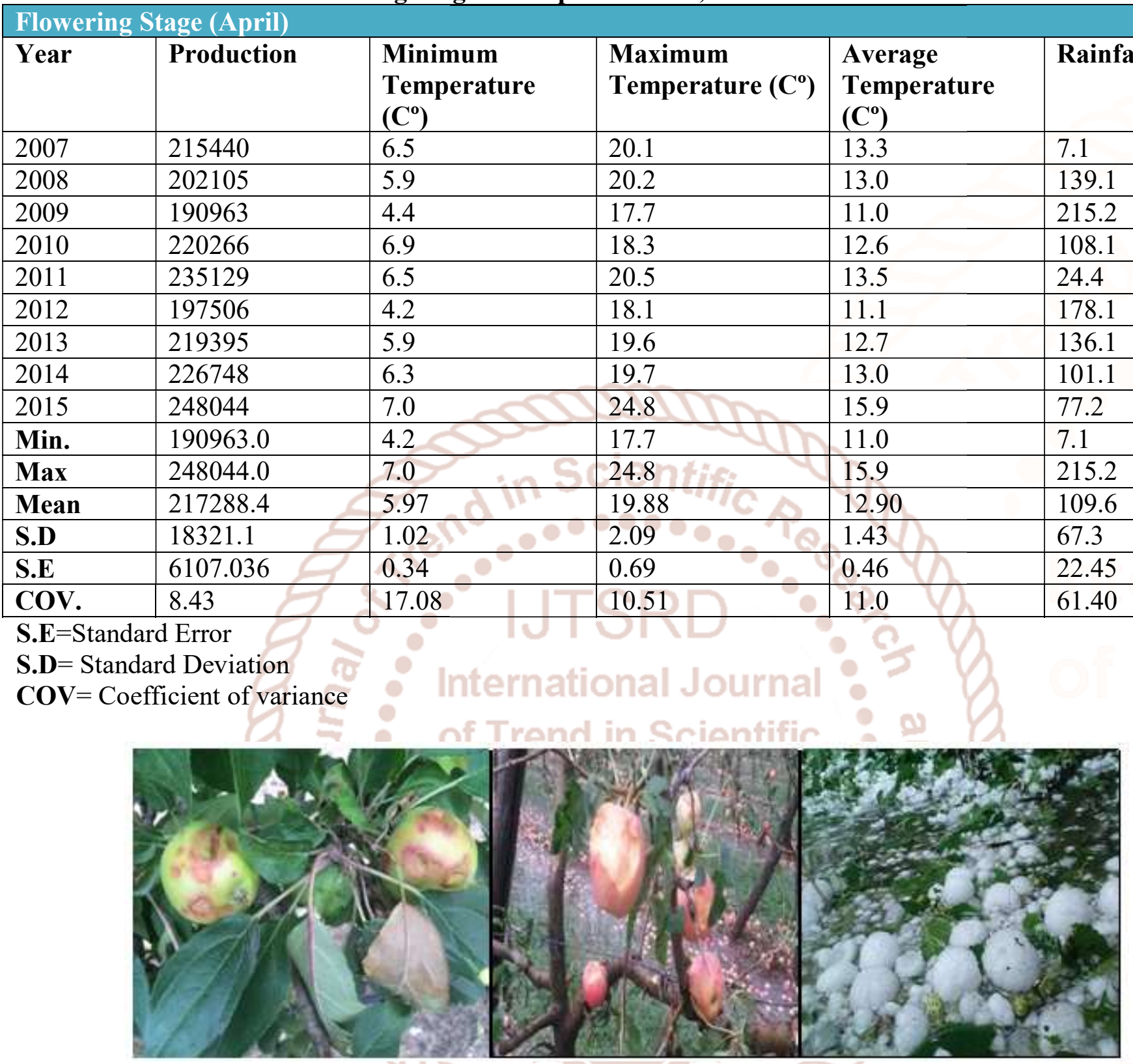

Fig. 2 Apple fruit damage and fall due to hails in Shopian

Table 1.3 Variation in apple production in relation to fluctuation in temperature and rain fall at Fruit Developmental Stage in Shopian district, Jammu and Kashmir

\begin{tabular}{|l|l|l|l|l|l|}
\hline \multicolumn{2}{|l|}{ (June-July) Fruit Developmental Stage } \\
\hline Year & Production & $\begin{array}{l}\text { Min. temp. } \\
(\text { Co })\end{array}$ & $\begin{array}{l}\text { Max. temp } \\
(\text { Co })\end{array}$ & $\begin{array}{l}\text { Av. temp. } \\
(\text { Co })\end{array}$ & Rainfall (mm) \\
\hline 2007 & 215440 & 15.2 & 27.7 & 21.5 & 139.1 \\
\hline 2008 & 202105 & 16.6 & 28.2 & 22.4 & 117.7 \\
\hline 2009 & 190963 & 13.1 & 26.0 & 19.6 & 215.2 \\
\hline 2010 & 220266 & 14.0 & 25.8 & 19.9 & 136.1 \\
\hline 2011 & 235129 & 15.4 & 28.2 & 21.8 & 127.6 \\
\hline 2012 & 197506 & 14.1 & 27.5 & 20.8 & 178.1 \\
\hline 2013 & 219395 & 15.7 & 29.0 & 22.4 & 108.1 \\
\hline 2014 & 226748 & 15.0 & 27.9 & 21.5 & 120.6 \\
\hline
\end{tabular}


International Journal of Trend in Scientific Research and Development (IJTSRD) ISSN: 2456-6470

\begin{tabular}{|l|l|l|l|l|l|}
\hline 2015 & 248044 & 15.2 & 27.0 & 21.1 & 119.1 \\
\hline Min. & 190963.0 & 13.1 & 25.8 & 19.6 & 108.1 \\
\hline Max & 248044.0 & 16.6 & 29.0 & 22.4 & 215.2 \\
\hline Mean & 217288.4 & 14.92 & 27.47 & 21.22 & 140.1 \\
\hline S.D & 18321.1 & 1.04 & 1.04 & 0.98 & 34.6 \\
\hline S.E & 6107.036 & 0.34 & 0.34 & 0.32 & 11.54 \\
\hline COV & 8.43 & 6.72 & 3.78 & 4.61 & 24.69 \\
\hline
\end{tabular}

\section{3) Winter:}

Winter temperature and precipitation especially in the form of snow are very crucial for introduction of dormancy, bud break and ensuring flowering in apples. Kumar and Yasir (2012) has reported that at least 1200 chilling hours are necessary for proper bud break and flowering in Delicious apples at South Kashmir conditions $^{3}$. However, most of the horticulturists are of the view that apple requires 1200-1500 hours of chilling below $7^{\circ} \mathrm{C}$ during winters for an expected good crop. If the chilling hours receive fall short of 1000 hours, it is expected that a poor crop year is in offing with staggered, delayed and sparse flowering resulting in poor fruit set. Good winter precipitation especially in the form of snow is most beneficial. Early rains or snow in, December and January are most beneficial in fulfilling chilling requirement as compared to late snowfall. The winter period of the district remains colder and extended compared to other apple producing belts of the state, so the chilling hours required below $7^{\circ} \mathrm{C}\left(45^{\circ} \mathrm{F}\right) 1200-1500$ hours are easily met. However the snowfall during the period shows a direct relationship for the minimum and maximum temperature (chilling hours) and hence with the production. The winter rainfall which is an indicator of lowering the temperature to provide the chilling requirement for bud formation does not show any significant relation with the production in winter period.

Table 1.4 Variation in apple production in relation to fluctuation in temperature, rain fall and Snowfall at Post Harvest Stage in Shopian district, Jammu and Kashmir

\begin{tabular}{|c|c|c|c|c|c|c|}
\hline \multicolumn{6}{|c|}{ Post-harvest Stage /Winter Conditions (December-February) } & \multirow{2}{*}{$\begin{array}{l}\text { Winter Chilling } \\
\text { (December- } \\
\text { February) } \\
\text { Snowfall (CMs) }\end{array}$} \\
\hline Year & Production & Min. temp. $\left(\mathrm{C}^{\mathrm{o}}\right)$ & $\begin{array}{l}\text { Max. temp } 0=0 \\
\left(C^{o}\right)\end{array}$ & $\begin{array}{l}\text { Av. temp. } \\
\left(\mathrm{C}^{\mathrm{o}}\right)\end{array}$ & $\begin{array}{l}\text { Rainfall } \\
(\mathrm{mm})\end{array}$ & \\
\hline 2007 & 215440 & -3.2 & 10.0 & 3.4 & 58.80 & 68.8 \\
\hline 2008 & 202105 & -2.9 & 7.7 & 2.4 & 187.2 & 36.5 \\
\hline 2009 & 190963 & -1.2 & 9.8 & 4.3 & 62.3 & 46.8 \\
\hline 2010 & 220266 & -2.2 & 10.7 & $4.25>$ & 166.6 & 18.5 \\
\hline 2011 & 235129 & -3.7 & 8.3 & 2.3 & 125.7 & 91.8 \\
\hline 2012 & 197506 & -1.4 & 7.2 & 2.9 & 106.8 & 40.5 \\
\hline 2013 & 219395 & -2.1 & 9.3 & 3.6 & 124.3 & 73.6 \\
\hline 2014 & 226748 & -3.5 & 8.3 & 2.4 & 76.4 & 72.9 \\
\hline 2015 & 248044 & -2.9 & 6.4 & 1.75 & 140.5 & 97.3 \\
\hline Min. & 190963.0 & -.3 .7 & 6.4 & 1.75 & 58.8 & 18.5 \\
\hline Max & 248044.0 & -1.2 & 10.7 & 4.3 & 187.2 & 97.3 \\
\hline Mean & 217288.4 & -2.5 & 8.63 & 3.0 & 116.5 & 60.3 \\
\hline S.D & 18321.1 & 0.89 & 1.41 & 0.90 & 44.9 & 26.4 \\
\hline S.E & 6107.036 & 0.29 & 0.47 & 0.30 & 14.9 & 8.82 \\
\hline $\mathrm{COV}$ & 8.43 & -35.6 & 16.3 & 30 & 38.5 & 43.7 \\
\hline
\end{tabular}

\footnotetext{
3 Kumar A, Mir Y (2012) Assessment of chilling requirement of different varieties of apple in South Kashmir, Progressive Horticulture, Volume : 44, Issue : 1, p. 86
} 
One among the vital indicators of climate variability is that the Kashmir valley recorded major floods at the flip of the century in September (apple harvest period) 2014. in line with horticulture department's report, out of 236058 hectare area under fruit crops, 127232 hectares has been affected owing to rains and floods in 2014- 15, "which has caused a huge loss to the growers". The floods have caused a loss of Rs 1,000 crores to the apple crop in Kashmir, threatening a collapse of the horticulture industry within the state (The Times of India Sep2014). The loss estimated from district Shopian was Rs.190 crore (Rising Kashmir -2016).

Climate variability and Apple Diseases: The intensity of apple diseases has increased from last few years in Kashmir valley as well as in the study area. The most affected diseases are apple Scab and Alternaria affecting the quantity and quality of apples. In Shopian during 2014, 10\% of the area has been affected due to Scab. The orchardists reported spurious pesticides and inclement weather the reason of diseases. Apple scab is caused by the fungus Venturia inaequalis. This disease additionally affects crabapple. Development of apple scab is favored by rainy, humid and cool spring weather conditions. If it is not properly controlled, it will cause scab lesions on fruits that will reduce fruit quantity and value ${ }^{4}$. Under the changing climate scenario existing fungi, microorganism and viruses may cause more damage to the crop. An increased number of sprays are now required for the routine control of pests. The number of sprays has increased from about four per year in 1980s to about 11 per year up to 2015. The disease like red mite and scab are common in each part of the valley due to the existing climate ${ }^{5}$.
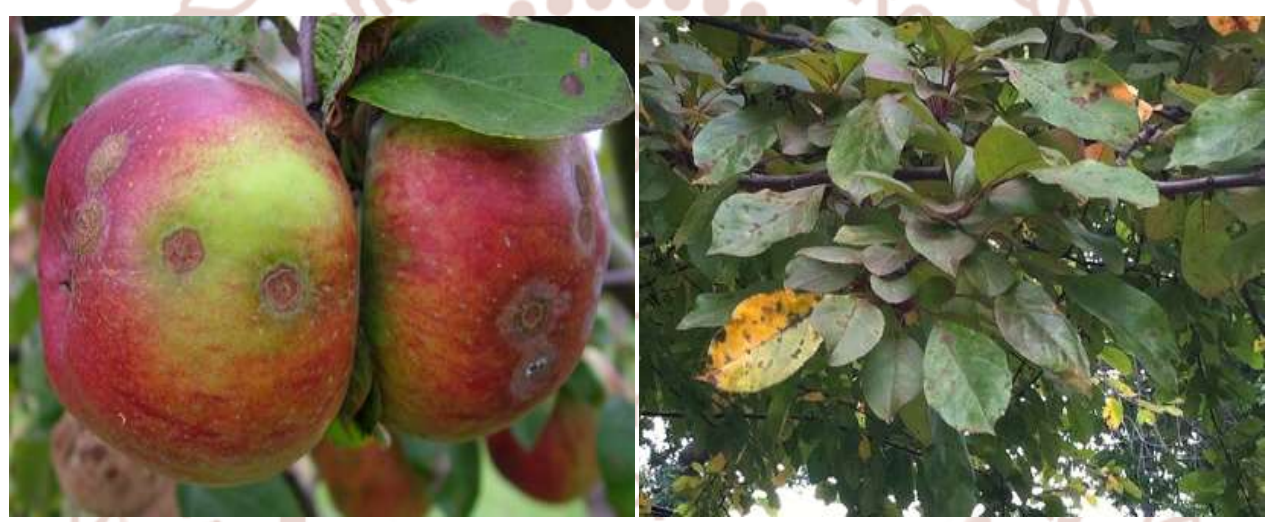

Fig. 3 Scab lesion on Apples and leaves

During the months of July-August 2013, apple orchards of Kashmir valley were suddenly struck with Alternaria disease which was so far considered a disease of minor importance as compared to apple scab. The disease spread like wild fire leading to very high severity and often resulted in extensive defoliation and fruit fall in almost all the orchards through the valley, resulting into a widespread epidemic. The various factors which lead to this epidemic were a possible effect of climate change leading to untimely prolonged rains following high temperatures. Dark, velvety spots might seem on the lower surface. Severely infected leaves become twisted and puckered and may drop early in the summer ${ }^{6}$. According to sample respondents in order to control the apple diseases the proportion of sprays of chemicals/fungicides/pesticides (leading input cost of production) have increased from 6-7 to 11-12 a year.

\footnotetext{
${ }^{4}$ Carisse, O. (2006). Apple Scab: Improving Understanding for Better Management, Agriculture and Agri-Food Canada, Publication, p. 7

${ }^{5}$ Wani, Y. (2015). A study on impact of climate change on horticulture sector in Jammu and Kashmir: an economic overview, International Journal of Scientific Research and Management, Vol. 5, Issue 7, pp. 6482-6483.

${ }^{5}$ Bhat, K. (2015). Alternaria epidemic of apple in Kashmir. African Journal of Microbiology Research, p. 83
} 

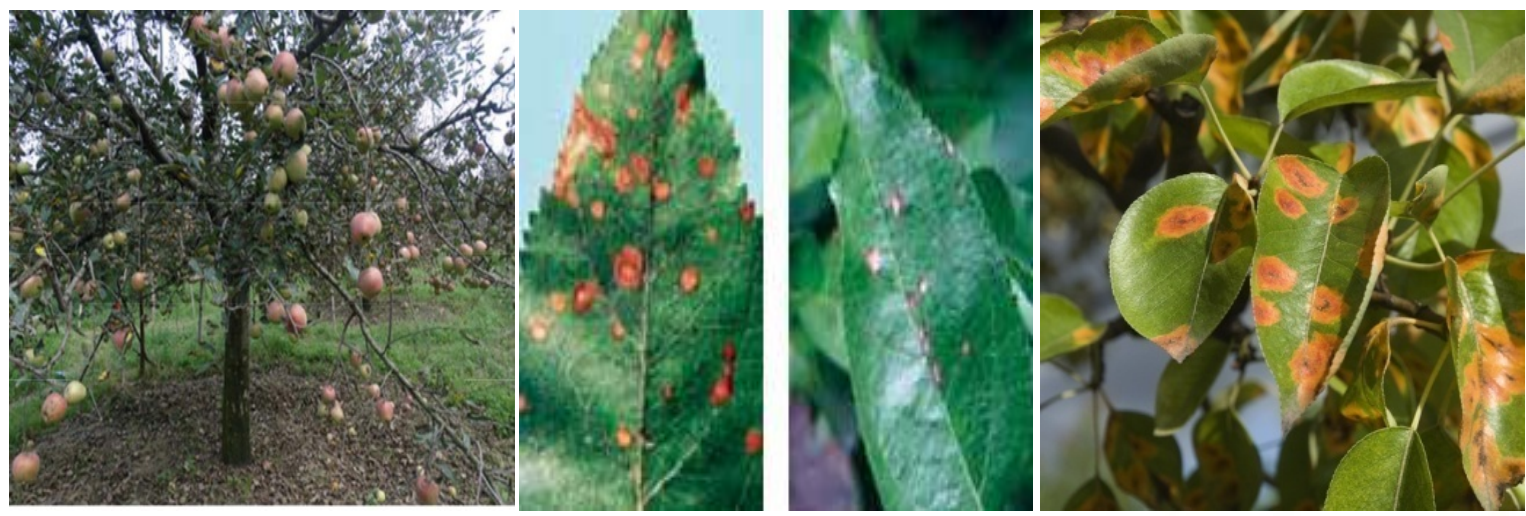

Fig. 4 Defoliation along with fruit drop due to Alternaria disease and lesions of Alternaria (leaf blotch) on leafs during epidemic of 2013 in Kashmir valley.

\section{Testing o Hypothesis}

Non linear regression analysis was used to run to see whether climatic parameters of minimum temperature, maximum temperature, rainfall and snowfall had any significant influence in apple production at three stages. The analysis was based on 9 years' monthly climate (rainfall, snowfall and temperature) as independent variables and apple production (dependent variable) of corresponding years. Nonlinear regression is a method of finding a nonlinear model of the relationship between the dependent variable and a set of independent variables. Unlike traditional linear regression, which is restricted to estimating linear models, nonlinear regression can estimate models with arbitrary relationships between independent and dependent variables.

\section{Flowering Stage (April)}

Table: 1.5 Impact of climate variability on apple production at Flowering Stage

\begin{tabular}{|l|l|l|l|l|l|l|}
\hline $\begin{array}{l}\text { Independent } \\
\text { variable }\end{array}$ & $\mathrm{R}$ - square & Multiple R & Adjusted R & Beta value & F-value & P-value \\
\hline Min & 0.69 & 0.83 & $\mathrm{DeV}$ & 0.64 & & \\
\hline Max & 0.62 & 0.78 & 0.56 & 0.47 & 15.6 & 0.005 \\
\hline Rainfall & 0.49 & 0.70 & $0.426-6.47$ & -0.10 & 6.83 & 0.05 \\
\hline
\end{tabular}

$\mathrm{H}_{\mathrm{a}}$ : There is a significant influence of climate variability on apple production during flowering stage.

The above table shows that impact of climate variability on apple production in flowering stage. It is inferred from the obtained statistical result that the obtained r-square value for minimum temperature is 0.69 i.e. $69 \%$. Also for the maximum temperature, the obtained $r$-square value is 0.62 i.e. $62 \%$. But in Rainfall the r-square value is 0.49 i.e. $49 \%$. Also from the obtained F-ratio values for all the parameters they are significant at 0.05 level. Based on the $\mathrm{P}$-values the stated alternative hypothesis is accepted. $\mathrm{P}<=0.05$. Further regarding the beta value for minimum and maximum temperature there is a positive impact and for rain fall there is negative impact. So it is concluded from the analysis that during the minimum temperature the production is highly influenced when compared with other variables. 
Figure 5 Impact of climate variability on apple production at Flow ering Stage

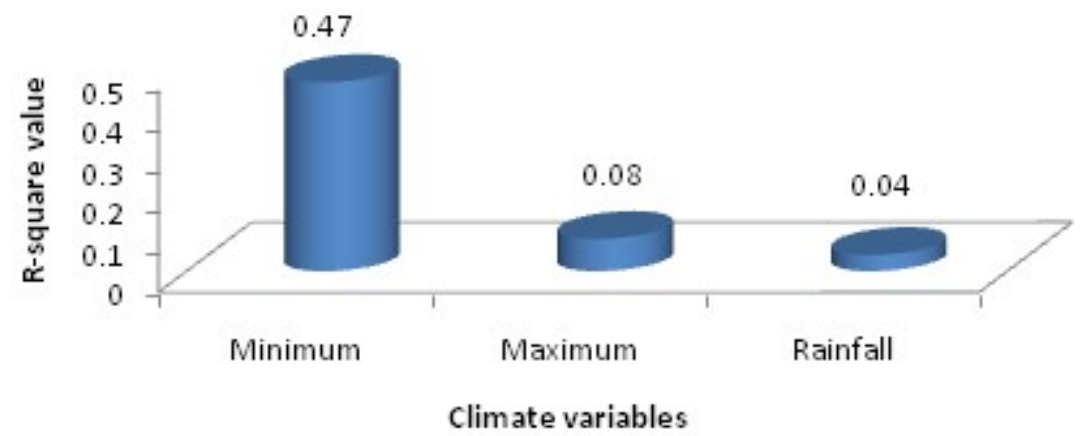

Fruit Developmental Stage (June-July)

Table: 1.6 Impact of climate variability on apple production in Fruit Developmental Stage

\begin{tabular}{|l|l|l|l|l|l|l|}
\hline $\begin{array}{l}\text { Independent } \\
\text { variable }\end{array}$ & $\mathbf{R}$ - square & Multiple R & Adjusted R & Beta value & F-value & P-value \\
\hline Min & 0.12 & 0.36 & 0.005 & -0.62 & 1.04 & 0.34 \\
\hline Max & 0.03 & 0.17 & -0.10 & -0.09 & 0.23 & 0.64 \\
\hline Rainfall & 0.48 & 0.69 & 0.40 & -1.27 & 6.46 & 0.03 \\
\hline
\end{tabular}

$\mathrm{H}_{\mathrm{a}}$ : There is a significant influence of climate variability on apple production during Fruit Developmental Stage.

The above table shows the impact of climate variability on apple production in Fruit Developmental Stage. It is inferred from the obtained statistical result that the obtained r-square value for minimum temperature is 0.12 i.e. $12 \%$. Also for the maximum temperature, the obtained $r$-square value is 0.03 i.e. $3 \%$. But in Rainfall the $r-$ square value is 0.48 i.e. $48 \%$. Also from the obtained F-ratio values for minimum and maximum temperature there is no significant influence in production. $\mathrm{P}>0.05$. But regarding the rainfall there is a significant influence. $\mathrm{P}<=0.05$. So, the stated alternative hypothesis is accepted only for rainfall $\mathrm{P}<=0.05$. Further regarding the beta value for all the parameters there is a negative impact. So it is concluded from the analysis that during the rainfall production is highly influenced when compared with other variables.

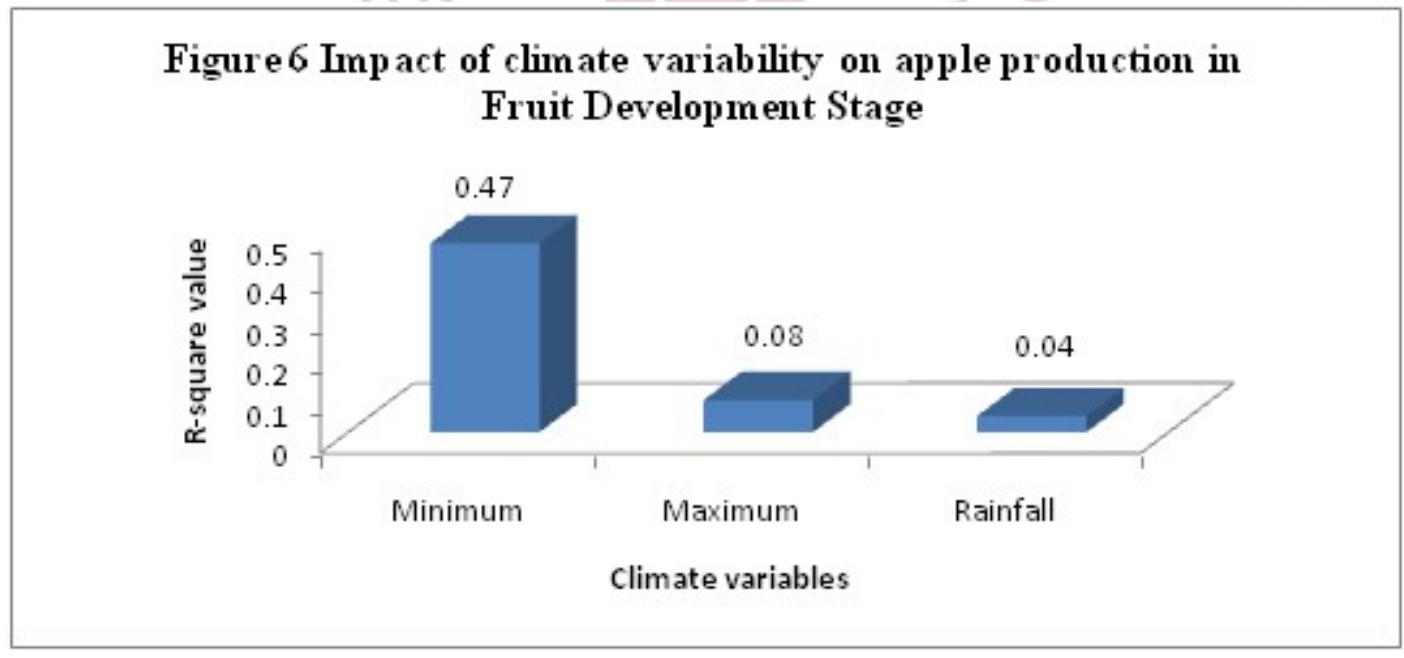


International Journal of Trend in Scientific Research and Development (IJTSRD) ISSN: 2456-6470

\section{Post-harvest Stage /Winter Conditions (December-February)}

Table: 1.7 Impact of climate rehabilitation on apple production in Post-harvest Stage

\begin{tabular}{|l|l|l|l|l|l|l|}
\hline $\begin{array}{l}\text { Independent } \\
\text { variable }\end{array}$ & $\mathbf{R}$ - square & Multiple R & Adjusted R & Beta value & F-value & P-value \\
\hline Min & 0.47 & 0.68 & 0.39 & -0.22 & 6.32 & 0.05 \\
\hline Max & 0.08 & 0.29 & -0.04 & 0.20 & 0.65 & 0.44 \\
\hline Rainfall & 0.04 & 0.20 & -0.09 & 0.44 & 0.30 & 0.59 \\
\hline Snowfall & 0.52 & 0.72 & 0.45 & 0.79 & 7.64 & 0.01 \\
\hline
\end{tabular}

$\mathrm{H}_{\mathrm{a}}$ : There is a significant influence of climate variability on apple production during the Post-harvest Stage.

The above table exhibits the impact of climate variability on apple production in Post-harvest Stage. It is inferred from the obtained statistical result that the obtained r-square value for minimum temperature is 0.47 i.e. $47 \%$. Also for the maximum temperature, the obtained r-square value is 0.08 i.e. $8 \%$, for rainfall the r-square value is 0.04 i.e. $4 \%$ and for snowfall the obtained $r$-square value is 0.52 i.e. $52 \%$. Based on the obtained F-ratio values there is a significant influence between minimum temperature vs. production and snowfall vs. production. $\mathrm{P}<=0.05$. But regarding the rainfall and maximum temperature there is no significant influence. $\mathrm{P}>0.05$. So, the stated alternative hypothesis is accepted only for minimum and snowfall $\mathrm{P}<=0.05$. Further regarding the beta value for all the parameters there is a positive impact except minimum temperature. So it is concluded from the analysis that during the snowfall production is highly influenced when compared with other climatic variables. In Post-harvest Stage the snowfall has high impact on production.

Figure 7 Imp act of climate rehabilitation on apple production in Post-harvest Stage

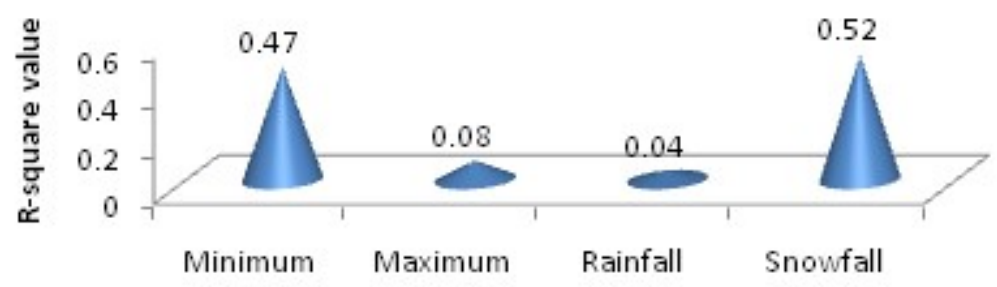

Climate variables

Table 1.8: Correlation coefficient (r-values) between fluctuating weather parameters and apple production in Shopian District, Jammu and Kashmir

Weather Parameters

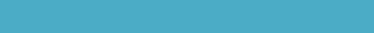

Apple Production Correlation coefficient

$0.831 * *$

0.360

$-0.689^{*}$

$0.789^{*}$

0.179

$-0.293$

$-0.703^{*}$

0.281

0.203

(December-February)

\begin{tabular}{l|l}
\hline Snowfall & Annual - Winter (December-February)
\end{tabular}

$0.728^{*}$


* Significant at 5\% level

** Significant at $1 \%$ level

It is also evident from the above correlation (Table 5.7) that all climatic parameters have significant relationship with apple production during flowering stage. Minimum and maximum temperature at flowering stage had positive and significant relationship with apple production (r. values $0.831^{* *}$ and $0.789 *$ respectively) in the study area. However, at the same stage rainfall had significant but negative correlation (r. value $-0.703 *$ ). Hence flowering stage is considered as the most crucial stage in apple production as far the climate is considered. Temperature during flowering should be around $20^{\circ} \mathrm{C}$ for proper anthesis, cross pollination and fruit-set. High temperature above $26^{\circ} \mathrm{C}$ or low temperature below $15^{\circ} \mathrm{C}$ during flowering especially around full bloom has adversely affected the fruit-set and productivity. Rainfall during the flowering period of apples reduces the potential for effective pollination and fruit set. The rain inhibits the foraging activities of all bee species and thus reduces pollen transfer and also rain inhibits the germination and growth of pollen on the stigma and results in pollen death. Thus, the cloudy and rainy weather during flowering especially at the time of bloom restricts the pollination and deteriorate the fruit-set as of the years 2009 and 2012 in the study area.

The climate variables during summer do not show a significant relationship with production. Again from correlation the minimum temperature during winter or post harvest stage shows a significant but negative correlation with production. Another important climatic parameter snowfall also shows positive significant relationship (r. value $0.728 *$ ) with apple production. Winter precipitation especially in the form of snow helps in providing winter chilling. Winter temperature and precipitation especially in the form of snow are very crucial for introduction of dormancy, bud break and ensuring flowering in apples. Apple requires 1200-1500 hours of chilling below $7^{\circ} \mathrm{C}$ during winters for an expected good crop. If the chilling hours receive fall short of 1000 hours, it is expected that a poor crop year is in offing with staggered, delayed and sparse flowering resulting in poor fruit set.

Thus, the findings show that, apple production in Shopian district, Jammu and Kashmir appears likely to deteriorate as a consequence of climate variability.

\section{Policy Implications/Suggestions}

On the basis of the above findings, the suggestions for improvement can be made on the following lines.

- To overcome the adverse effects of fluctuating weather conditions proper selection of suitable cultivars as per the altitude and microclimatic conditions of the area is required with the proper proportion of pollinizing varieties

$>$ Among the standard varieties there should be more proportion of regular bearing varieties than the delicious varieties.

Providing 4-5 beehives per hectare for adequate pollination during flowering.

Where adequate proportion of pollinizing varieties has not been provided, top working of the trees with pollinizing varieties should be done.

There is an urgent need to go for high density plantation in different temperate fruit crops particularly for apple. By the use of this technology, per unit production can be increased. There ll are instances where a high density plantation has resulted in productivity of 70.0tonnes per hectare in some on years

Concerted efforts are required for the introduction and evaluation of new promising rootstocks of different temperate fruits under different climatic conditions.

Recommended spray schedule of chemicals should be followed to control pests and diseases at proper time.

Judicious use of insecticides/pesticides/fungicides should be made since their excessive use can increase tolerance and eradicate many natural enemies of these pests. 